\title{
Arahan Peningkatan Kualitas Lingkungan Kawasan Permukiman Kumuh Berat di Kelurahan Ciketingudik dan Sumurbatu Kota Bekasi
}

\author{
Anindita Wilandari dan Haryo Sulistyarso \\ Departemen Perencanaan Wilayah dan Kota, Fakultas Teknik Sipil dan Perencanaan, Institut Teknologi \\ Sepuluh Nopember (ITS) \\ e-mail: haryo.its@gmail.com
}

\begin{abstract}
Abstrak-Salah satu wilayah permukiman kumuh berat di Kota Bekasi terletak di sekitar TPST (Tempat Pengelolaan Sampah Terpadu) Bantargebang yang termasuk ke dalam wilayah administrasi Kelurahan Ciketingudik dan Kelurahan Sumurbatu, Kecamatan Bantargebang. Kekumuhan yang ada dapat dilihat dari kualitas lingkungan yang menurun serta ketersediaan infrastruktur yang tidak memadai. Berdasarkan isu tersebut, maka tujuan dari penelitian ini adalah untuk menentukan arahan yang tepat untuk meningkatkan kualitas lingkungan permukiman kumuh di wilayah tersebut. Terdapat tiga metode yang digunakan yaitu (1) Delphi, untuk menganalisis variabel penyebab kumuh, (2) AHP (Analytical Hierarchy Process), untuk menentukan prioritas peningkatan kualitas variabel penyebab kumuh, dan (3) Deskriptif kualitatif, untuk menentukan arahan. Hasil penelitian ini menunjukkan bahwa jaringan air bersih merupakan prioritas tertinggi dalam peningkatan kualitas lingkungan dengan arahan sebagai berikut : (a) Penutupan sumur bor yang tercemar di RW 01 Sumurbatu RT 01 - 07. Penutupan dapat dilakukan dengan cor semen, (b) Revitalisasi sumur artesis yang telah tidak berfungsi di RT 01/03 dan 02/04 Sumurbatu, dan (c) Pengadaan HIPPAM di RW 04 Ciketingudik, RW 01, 03 (RT 02 dan 05), 04 Sumurbatu.
\end{abstract}

Kata Kunci-Permukiman Kumuh Berat, Prioritas Peningkatan Kualitas, Peningkatan Kualitas Lingkungan.

\section{PENDAHULUAN}

$\mathrm{S}_{\mathrm{t}}^{\mathrm{A}}$ ALAH satu lokasi permukiman kumuh di Kota Bekasi terletak di permukiman sekitar TPST Bantargebang. Permukiman kumuh tersebut terbagi atas kumuh ringan, sedang, dan berat. Penelitian ini difokuskan hanya pada kawasan permukiman kumuh berat yang terletak di Kelurahan Ciketingudik (RW 1, RW 4, RW 5) dan Kelurahan (RW 1, RW 2, RW 3, RW 4, RW 5).

Terdapat beberapa isu lingkungan yang terjadi pada kawasan permukiman kumuh tersebut seperti pelayanan persamapahan, air bersih, dan drainase yang tidak baik serta jaringan jalan yang tidak sesuai persyaratan teknis baik dari segi perkerasan maupun kelengkapannya. Selain itu, tidak terdapat hidran kebakaran dan pembuangan air limbah yang masih bersatu dengan saluran drainase. Terkait kedekatannya dengan TPST Bantargebang, permasalahan lingkungan utama yang terjadi adalah pencemaran air tanah pada sumur warga oleh interupsi air lindih yang bersumber dari TPST. [1]

Upaya penanganan permukiman kumuh yang telah dilakukan Pemerintah Kota Bekasi diantaranya adalah memperbaiki rumah tidak layak huni melalui program RUTILAHU dengan memberikan bantuan berkisar 12-15 juta per hunian serta pembangunan sumur-sumur artesis dan MCK umum. Akan tetapi upaya penanganan tersebut belum berhasil memberantas kekumuhan yang ada.

Oleh karena itu, dibutuhkan arahan peningkatan kualitas lingkungan yang tepat untuk menangani permasalahan permukiman kumuh yang ada di Kelurahan Ciketingudik dan Sumur Batu, Kota Bekasi. [2]

\section{METODE PENELITIAN}

Jenis penelitian yang dilakukan adalah penelitian kualitatif. Sementara pendekatannya menggunakan rasionalistik. Variabel penelitian ini dikelompokkan ke dalam 6 faktor, yaitu (1) Faktor infrastruktur, terdiri dari jaringan air bersih, sanitasi lingkungan, fasilitas persampahan, saluran air hujan/drainase, jaringan jalan, ruang terbuka, keterbatasan lahan permukiman; (2) Faktor peran pemerintah, terdiri dari kemampuan pemerintah dalam menyediakan hunian layak; (3) Faktor ekonomi, terdiri dari tingkat pendapatan dan jenis pekerjaan informal; (4) Faktor kependudukan, terdiri dari laju pertumbuhan, urbanisasi, kepadatan penduduk, tingkat pendidikan; (6) Faktor standar pemanfaatan ruang sekitar TPA, terdiri dari bahaya banjir, bahaya longsor, jarak terhadap permukiman, jarak terhadap badan air, kawasan lindung, bau, transportasi sampah.

Penelitian ini terdiri dari tiga sasaran. Sasaran pertama yaitu analisis variabel penyebab kekumuhan menggunakan metode Delphi. Stakeholders yang berpartisipasi adalah Bappeda Kota Bekasi, Dinas PUPR, Dinas Bangunan dan Permukiman, Dinas Lingkungan Hidup DKI Jakarta, Kelurahan Ciketingudik, Kelurahan Sumurbatu, Akademisi, dan perwakilan warga. Sasaran kedua yaitu analisis prioritas variabel penyebab kumuh untuk peningkatan kualitas lingkungan menggunakan metode Analytical Hierarchy Process (AHP). AHP menggunakan bantuan Expert Choice 11 dan respondennya terdiri dari Bappeda Kota Bekasi, Dinas PUPR, Dinas Bangunan dan 
Permukiman, Dinas Lingkungan Hidup DKI Jakarta, dan Akademisi. Sasaran ketiga yaitu penentuan arahan peningkatan kualitas lingkungan menggunakan metode deskriptif kualitatif. Metode ini mengomparasikan antara kondisi eksisting dari variabel penyebab kekumuhan, kebijakan, dan best practice.

\section{HASIL DAN DISKUSI}

Wilayah studi terletak pada Kelurahan Ciketingudik dan Sumurbatu, Kecamatan Bantargebang, Kota Bekasi. Wilayah ini berbatasan langsung dengan TPST Bantargebang. Batas administrasi wilayah studi adalah sebagai berikut :

\section{Sebelah utara : Kec. Pedurenan dan Kec. Cimuning}

Sebelah timur : Kabupaten Bekasi

Sebelah selatan : Kabupaten Bogor

Sebelah barat : RW 2, 3, 6, 7, 8, 9 Kel. Ciketingudik

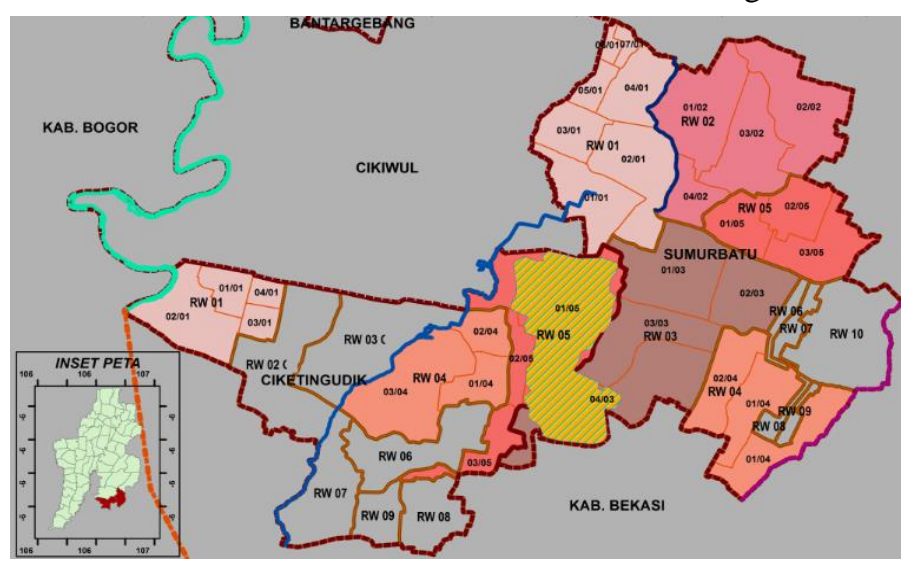

Gambar 1. Peta Batas Wilayah Studi (Participatory Mapping, 2017).

\section{A. Analisis Variabel Penyebab Kekumuhan di Kelurahan Ciketingudik dan Sumurbatu}

Analisis menggunakan metode Delphi yang dilakukan dalam tiga tahap. Pada Delphi tahap pertama, terdapat beberapa variabel yang disetujui dan tidak disetujui menyebabkan kekumuhan. Selain itu, terdapat beberapa variabel temuan baru. Variabel yang belum mencapai tahap iterasi akan digunakan pada Delphi tahap berikutnya. Keterangan tiap-tiap variabel dapat dilihat pada Tabel 1.

Tabel 1.

Hasil Delphi Tahap 1

1. Variabel yang disetujui . Tingkat pendapatan, urbanisasi, jaringan

1. responden air bersih, dan jarak terhadap badan air.

2. Variabel yang tidak Ruang terbuka, bahaya banjir, bahaya longsor, dan kawasan lindung.

3esadaran dan kepedulian warga,

3. Variabel temuan baru : ketersediaan hydran, listrik, dan kebakaran. Kemampuan pemerintah, jenis pekerjaan $\begin{array}{lrl}\text { Variabel yang informal, laju pertumbuhan, kepadatan } \\ \text { dilanjutkan ke tahap } 2 & \text { penduduk, tingkat pendidikan, sanitasi, }\end{array}$ 4ilanjutkan ke tahap 2
(belum mencapai : fasilitas persampahan, saluran drainase, (belum mencapai jaringan jalan, keterbatasan lahan permukiman, jarak terhadap permukiman, bau, dan transportasi sampah.

Pada Delphi tahap kedua, input yang digunakan adalah variabel yang belum mencapai iterasi seperti yang terdapat pada Tabel 1. Sementara itu, tidak ada temuan variabel baru pada tahap ini. Adapun hasilnya dapat dilihat pada Tabel 2.

Tabel 2

Hasil Delphi Tahap 2

Jenis pekerjaan informal, kesadaran dan Variabel yang disetujui :
responden

2. Variabel yang tidak : disetujui responden

$$
\text { Variabel yang }
$$

dilanjutkan ke tahap 2

(belum mencapai iterasi)

Pada Delphi tahap ketiga, input yang digunakan adalah variabel yang belum mencapai iterasi pada Delphi tahap kedua seperti pada Tabel 2. Tidak terdapat temuan variabel baru pada tahap ini, dan hasilnya dapat dilihat pada Tabel 3.

Tabel 3.

Hasil Delphi Tahap 3

1. Variabel yang disetujui Kemampuan pemerintah dan tingkat

1. responden

2. Variabel yang tidak

disetujui responden

Variabel yang

dilanjutkan ke tahap 2
(belum mencapai

iterasi)

Berdasarkan hasil analisis Delphi tahap pertama hingga ketiga tersebut, maka didapatkan variabel-variabel yang disetujui stakeholders menjadi penyebab kekumuhan di wilayah studi. Berikut adalah variabel penyebab kumuh beserta alasannya.

Tabel 4.

Faktor dan Variabel Penyebab Kekumuhan

\begin{tabular}{|c|c|c|}
\hline Faktor & Variabel & Alasan \\
\hline $\begin{array}{l}\text { Peran pemerin } \\
\text { tah }\end{array}$ & $\begin{array}{l}\text { Kemampuan } \\
\text { pemerintah dalam } \\
\text { menyediakan hunian } \\
\text { yang layak }\end{array}$ & $\begin{array}{l}\text { Kemampuan pemerintah dalam } \\
\text { menyediakan hunian yang layak } \\
\text { belum signifikan. }\end{array}$ \\
\hline \multirow{6}{*}{ Kependudukan } & $\begin{array}{l}\text { Jenis } \\
\text { informal }\end{array}$ & $\begin{array}{l}\text { Sebagian besar tidak memiliki } \\
\text { pekerjaan tetap dan terdapat } \\
\text { pengangguran. }\end{array}$ \\
\hline & Tingkat pendapatan & $\begin{array}{l}\text { Pendapatan sebagian besar } \\
\text { warga masih di bawah UMR. }\end{array}$ \\
\hline & & $\begin{array}{l}\text { Pendatang mendirikan hunian } \\
\text { temporer di lahan kosong tanpa }\end{array}$ \\
\hline & Urbanisasi & $\begin{array}{l}\text { MCK pribadi dan fasilitas yang } \\
\text { tidak memadai terkesan tidak } \\
\text { teratur. }\end{array}$ \\
\hline & Tingkat pendidikan & Kualitas pendidikan rendah. \\
\hline & $\begin{array}{l}\text { Kesadaran dan } \\
\text { kepedulian warga }\end{array}$ & $\begin{array}{l}\text { Kesadaran dan kepedulian } \\
\text { warga masih rendah. }\end{array}$ \\
\hline \multirow{4}{*}{$\begin{array}{l}\text { Infrastruktur } \\
\text { permukiman }\end{array}$} & Jaringan air bersih & $\begin{array}{l}\text { Air tanah tercemar dan PDAM } \\
\text { belum menjangkau warga. }\end{array}$ \\
\hline & Fasilitas persampahan & $\begin{array}{l}\text { Tidak terdapat sistem } \\
\text { persampahan. }\end{array}$ \\
\hline & $\begin{array}{l}\text { Saluran } \\
\text { hujan/drainase }\end{array}$ & Saluran drainase terputus. \\
\hline & Jaringan jalan & $\begin{array}{l}\text { Perkerasan jalan dalam kondisi } \\
\text { tidak baik. }\end{array}$ \\
\hline Bahaya & Bahaya kebakaran & $\begin{array}{l}\text { Terdapat kemungkinan } \\
\text { terjadinya kebakaran mengingat } \\
\text { sebagian wilayah merupakan } \\
\text { pemukiman padat bangunan. }\end{array}$ \\
\hline $\begin{array}{l}\text { Standard } \\
\text { pemanfaatan } \\
\text { ruang sekitar }\end{array}$ & $\begin{array}{l}\text { Jarak terhadap badan } \\
\text { air }\end{array}$ & $\begin{array}{l}\text { Kali Kramat hanya berjarak } 590 \\
\text { km dari TPST dan kondisinya } \\
\text { tercemar. }\end{array}$ \\
\hline
\end{tabular}




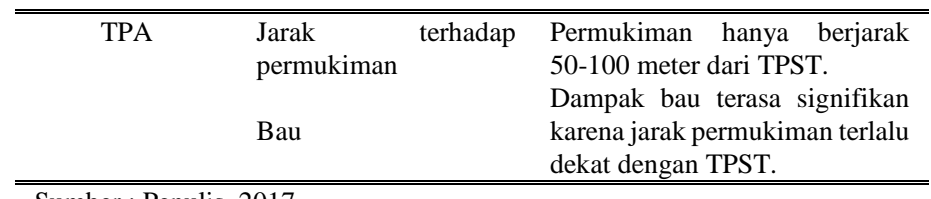

Sumber : Penulis, 2017

\section{B. Prioritas Variabel Penyebab Kekumuhan untuk Peningkatan Kualitas Lingkungan di Kelurahan Ciketingudik dan Kelurahan Sumurbatu}

Metode yang digunakan dalam menyusun prioritas adalah AHP. Adapun input yang digunakan adalah variabel penyebab kumuh yang telah teridentifikasi sebelumnya. Berikut adalah prioritas tiap-tiap faktor dan variabel beserta bobotnya :

Tabel 5.

Prioritas Faktor dan Variabel untuk Peningkatan Kualitas Lingkungan Permukiman Kumuh

\begin{tabular}{|c|c|c|c|}
\hline \multicolumn{2}{|r|}{ Prioritas Faktor } & \multicolumn{2}{|r|}{ Prioritas Variabel } \\
\hline \multirow{4}{*}{1} & & 1 & Jaringan air bersih $(0,531)$ \\
\hline & Infrastruktur & 2 & Fasilitas persampahan $(0,270)$ \\
\hline & $\begin{array}{l}\text { permukiman } \\
(0,360)\end{array}$ & 3 & $\begin{array}{l}\text { Saluran air hujan/drainase } \\
(0,137)\end{array}$ \\
\hline & & 4 & Jaringan jalan $(0,063)$ \\
\hline 2 & $\begin{array}{c}\text { Peran pemerintah } \\
(0,299)\end{array}$ & 1 & $\begin{array}{l}\text { Kemampuan pemerintah dalam } \\
\text { menyediakan hunian yang layak }\end{array}$ \\
\hline \multirow{3}{*}{3} & Standard pemanfaatan & 1 & $\begin{array}{l}\text { Jarak terhadap permukiman } \\
(0,667)\end{array}$ \\
\hline & ruang sekitar IPA & 2 & Bau $(0,202)$ \\
\hline & & 3 & Jarak terhadap badan air $(0,131)$ \\
\hline \multirow[t]{3}{*}{4} & Ekonomi $(0,057)$ & 1 & Tingkat pendapatan $(0,550)$ \\
\hline & EKONOInI $(0,05 /)$ & 2 & Jenis pekerjaan informal $(0,450)$ \\
\hline & & 1 & Urbanisasi $(0,510)$ \\
\hline \multirow[t]{2}{*}{5} & Kependudukan $(0,046)$ & 2 & $\begin{array}{l}\text { Kesadaran dan kepedulian warga } \\
(0,249)\end{array}$ \\
\hline & & 3 & Tingkat pendidikan $(0,241)$ \\
\hline 6 & Bahaya $(0,031)$ & 1 & Kebakaran \\
\hline
\end{tabular}

C. Arahan Peningkatan Kualitas Lingkungan Permukiman Kumuh di Kelurahan Ciketingudik dan Kelurahan Sumurbatu

Berdasarkan analisis prioritas pada tahap sebelumnya, didapatkan hasil bahwa infrastruktur permukiman merupakan prioritas peningkatan kualitas tertinggi. Oleh karena itu, analisis arahan akan difokuskan pada variabel yang termasuk ke dalam faktor ini saja. Arahan dihasilkan dengan membandingkan antara kondisi eksisting tiap-tiap variabel penyebab kumuh, kebijakan terkait, dan best practice. Berikut adalah prosesnya.

Tabel 6.

Analisis Variabel Jaringan Air Bersih

\begin{tabular}{|c|c|c|}
\hline Kondisi Eksisting & Kebijakan & Best Practice \\
\hline \multirow{8}{*}{$\begin{array}{l}\text { Tidak ada pelayanan } \\
\text { PDAM, air tanah } \\
\text { tercemar (RW } 04 \\
\text { Ciketingudik dan RW } \\
01, \quad 02, \quad 03, \quad 04 \\
\text { Sumurbatu) oleh } \\
\text { interupsi air lindih } \\
\text { TPST, dan terdapat } 5 \\
\text { sumur artesis (2 tidak } \\
\text { berfungsi). }\end{array}$} & Permen & Penyediaan \\
\hline & $\begin{array}{l}\text { Tahun } 2008 \text { Pasal } 46 \\
\text { (menutup sumur bor }\end{array}$ & Bersih pada Kawasan \\
\hline & atau & Pesisir \\
\hline & tercemar) & Lamongan [6]. \\
\hline & Permen & - Melakukan \\
\hline & $\begin{array}{l}\text { Tahun } 2008 \text { Pasal } 53 \\
\text { (Pengeboran/ } \\
\text { penggalian air tanah } \\
\text { wajib } \\
\text { mempertimbangkan }\end{array}$ & $\begin{array}{l}\text { kerjasama antara } \\
\text { pemerintah daerah, } \\
\text { untuk } \\
\text { pengembangan }\end{array}$ \\
\hline & kondisi lingkungan & $\begin{array}{l}\text { HIPPAM. } \\
\text { Membuat }\end{array}$ \\
\hline & $\begin{array}{l}\text { RPJMD 2013-2018 } \\
\text { (Perluasan pelayanan } \\
\text { air bersih) [5]. }\end{array}$ & $\begin{array}{l}\text { bor air bersih, } \\
\text { melalui } \\
\text { pengembangan } \\
\text { HIPPAM. }\end{array}$ \\
\hline
\end{tabular}

Sumber : Penulis, 2017

Mengembangkan
HIPPAM dengan
sumber embung
dan waduk
penangkapan air
hujan (PAH) untuk
desa/kelurahan
yang memiliki
sumber air tanah
langka.

Berdasarkan komparasi kondisi eksisting, kebijakan, dan best practice di atas, maka arahan yang tepat untuk meningkatkan kualitas air bersih di wilayah studi adalah penutupan sumur bor yang tercemar di RW 01 Sumurbatu RT 01 - 07 yang dapat menggunakan semen, revitalisasi sumur artesis yang telah tidak berfungsi di RT 01/03 dan 02/04 Sumurbatu, serta pengadaan HIPPAM di RW 04 Ciketingudik, RW 01, 03 (RT 02 dan 05), 04 Sumurbatu karena kondisi air tanah yang tecemar dan belum tersedia sumur artesis.

Tabel 7.

Analisis Variabel Fasilitas Persampahan

\begin{tabular}{|c|c|c|}
\hline Kondisi Eksisting & Kebijakan & Best Practice \\
\hline \begin{tabular}{lr}
\multicolumn{2}{l}{ Tidak ada manajemen } \\
sampah, & kurangnya \\
kesadaran & warga, \\
pengelolaan & TPST \\
dilakukan & secara \\
tunggal & oleh \\
Pemerintah & DKI \\
Jakarta. &
\end{tabular} & $\begin{array}{lr}\text { RTRW } & \text { Bekasi } \\
\text { 2011-2031 } & \text { (Menuntut } \\
\text { kebutuhan } & \text { green } \\
\text { infrastructue } & \text { dan } \\
\text { penanganan } & \text { sampah } \\
\text { dengan pola } & \text { 3R) } \\
\text { [7], } \\
\text { RPJMD } & \text { Bekasi } \\
\text { 2013-2018 } & \\
\text { (Mengolah } & \text { sampah } \\
\text { yang } & \text { berbasis } \\
\text { teknologi } & \text { dan } \\
\text { partisipasi). } & \end{array}$ & $\begin{array}{l}\text { Pengelolaan } \\
\text { Persampahan di Kota } \\
\text { Semarang [8] } \\
\text { - Menambah sarana } \\
\text { prasana } \\
\text { pengelolaan, } \\
\text { pengangkutan, dan } \\
\text { pengolah sampah } \\
\text { - Mengadakan } \\
\text { lomba kebersihan } \\
\text { lingkungan } \\
\text { - Pembentukan } \\
\text { pasgad (pasukan } \\
\text { sapu jagad) }\end{array}$ \\
\hline
\end{tabular}

Sumber : Penulis, 2017

Berdasarkan komparasi kondisi eksisting, kebijakan, dan best practice di atas, maka arahan yang tepat untuk meningkatkan kualitas fasilitas persampahan di wilayah studi adalah penyediaan bak sampah di tiap rumah warga dan tiap RW, pengadaan sistem pengangkutan sampah dengan rute rumah warga - bak sampah RW - TPST dan alat angkut berupa motor bak untuk menyesuaikan dengan dimensi jalan, pemberian reward untuk meningkatkan partisipasi warga dalam penerapan pola 3R dan menghentikan kebiasaan membakar sampah, serta mengadakan kerjasama antar daerah dengan pihak swasta untuk mengolah sampah organik di TPST sehingga bisa meminimalisir residu sampah.

Tabel 8.

Analisis Variabel Saluran Air Hujan/Drainase

\begin{tabular}{|c|c|c|}
\hline Kondisi Eksisting & Kebijakan & Best Practice \\
\hline \multirow{7}{*}{$\begin{array}{l}\text { Saluran drainase tipe } \\
\text { terbuka, diameter } 20 \\
40 \mathrm{~cm} \text {, kedalaman } \\
\pm 30 \mathrm{~cm}, \quad \text { terdapat } \\
\text { saluran } \quad \text { drainase } \\
\text { terputus. }\end{array}$} & RPJMD & Penataan Drainase di \\
\hline & 2013-2018 & Kepanjen \\
\hline & (Terpenuhinya & Malang [9] \\
\hline & kebutuhan & - Normalisasi \\
\hline & Indikasi & - Saluran baru \\
\hline & drainase & - Pengurangan beban \\
\hline & $\begin{array}{l}\text { dalam kondisi tidak } \\
\text { tersumbat). }\end{array}$ & $\begin{array}{l}\text { - Penampang saluran } \\
\text { ganda }\end{array}$ \\
\hline
\end{tabular}

Sumber : Penulis, 2017

Berdasarkan komparasi kondisi eksisting, kebijakan, dan best practice di atas, maka arahan yang tepat untuk meningkatkan 
kualitas saluran air hujan/drainase di wilayah studi adalah mengadakan saluran baru dengan sistem drainase terpadu sehingga dapat mengalirkan air dari saluran tersier ke saluran sekunder serta melakukan pelebaran diameter saluran, terutama pada RW 01 Ciketingudik dan RW 01, 05 Sumurbatu.

Tabel 9.

Analisis Variabel Jaringan Jalan

\begin{tabular}{|c|c|c|}
\hline Kondisi Eksisting & Kebijakan & Best Practice \\
\hline Telah menerima & RPJMD & - \\
\hline 40.000 unit lampu & 2013-2018 & \\
\hline dan $\quad 10.000$ & (Mengamanatkan & \\
\hline diantaranya & program & \\
\hline dialokasikan untuk & pemeliharaan & \\
\hline Kec. Bantargebang. & dan jembatan serta & \\
\hline Akan tetapi, tiang & peningkatan fasilitas & \\
\hline lampu belum tersedia. & $\begin{array}{l}\text { penerangan } \\
\text { umum). }\end{array}$ & \\
\hline
\end{tabular}

Sumber : Penulis, 2017

Berdasarkan komparasi kondisi eksisting, kebijakan, dan best practice di atas, maka arahan yang tepat untuk meningkatkan kualitas jaringan jalan di wilayah studi adalah pengadaan tiang lampu bagi ruas-ruas jalan tanpa penerangan jalan umum (PJU) serta perbaikan perkerasan jalan terutama pada Kelurahan Ciketingudik (RW 01, 04, 05) dan Kelurahan Sumurbatu (RW 01, 03, 05).

\section{KESIMPULAN}

Penelitian ini bertujuan untuk merumuskan arahan peningkatan kualitas lingkungan kawasan permukiman kumuh berat berdasarkan penyebab kekumuhannya. Berikut ini merupakan hasil yang diperoleh dari penelitian ini :

1. Prioritas tertinggi adalah peningkatan kualitas jaringan air bersih dikarenakan kondisinya yang telah mengalami pencemaran oleh air lindih TPST. Arahan yang diusulkan terkait isu tersebut adalah penutupan sumur bor yang tercemar, revitalisasi sumur artesis, dan pemerataan distribusi air bersih oleh PDAM.

2. Beberapa arahan lain dalam meningkatkan kualitas lingkungan di wilayah studi adalah terkait penyediaan serta perbaikan prasarana dan sarana lingkungan, pemberdayaan ekonomi masyarakat, dan peningkatan peran pemerintah Kota Bekasi.

\section{DAFTAR PUSTAKA}

[1] RPKPP Kota Bekasi Tahun 2016. 2016.

[2] A. Wilandari, "Arahan Peningkatan Kualitas Lingkungan Kawasan Permukiman Kumuh Berat di Kelurahan Ciketingudik dan Sumurbatu Kota Bekasi," Institut Teknologi Sepuluh Nopember, 2017. 